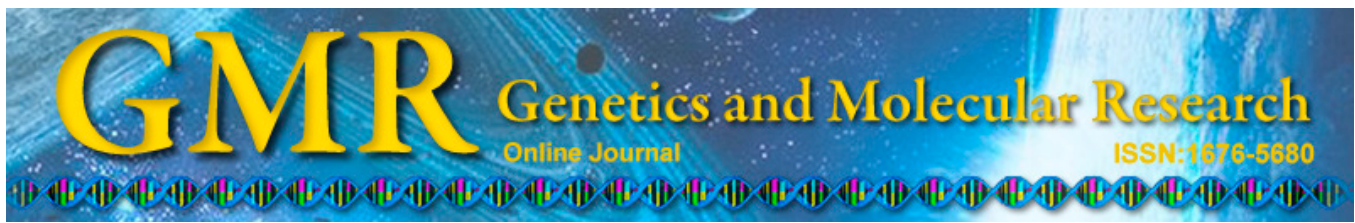

\title{
Dopamine receptor D1 but not D3 essential for morphine-induced conditioned responses
}

\author{
Y.P. Wang ${ }^{1}$, S.G. Wei ${ }^{1}$, Y.S. Zhu ${ }^{1}$, B. Zhao ${ }^{1}$, X. Xun ${ }^{1}$ and J.H. Lai ${ }^{1,2}$ \\ ${ }^{1}$ Key Laboratory of Forensic Science of Ministry of Public Health, \\ Xi' an Jiaotong University, Xi'an, Shaanxi, China \\ ${ }^{2}$ Key Laboratory of Environment and Genes Related to Diseases, \\ Ministry of Education, Xi'an Jiaotong University, Xi'an, Shaanxi, China \\ Corresponding author: J.H. Lai \\ E-mail: laijh1011@mail.xjtu.edu.cn / wyp853@163.com
}

Genet. Mol. Res. 14 (1): 180-189 (2015)

Received February 28, 2014

Accepted August 2, 2014

Published January 16, 2015

DOI http://dx.doi.org/10.4238/2015.January.16.1

ABSTRACT. Recent studies indicate the involvement of dopamine receptors D1 and D3 in the regulation of locomotor stimulant and conditioned responses to morphine in mice. Moreover, expression of brain-derived neurotrophic factor (BDNF) may be modulated by D1 and D3 receptor activities in the nucleus accumbens (NAc) and prefrontal cortex (PFC). However, the underlying interactions between D1 and D3 receptors and BDNF in the expression of behavioral responses controlled by drug-associated cues have not yet been fully elucidated. In this study, we used dopamine receptor mutant mice to explore the roles of the D1 and D3 receptors in locomotion and morphine-induced place preference; furthermore, we investigated the effects of morphine on BDNF expression in the NAc and PFC of the mouse brain. Our results show that D1 receptor but not D3 receptor mutant mice had decreased sensitivity to acute morphine-induced $(10 \mathrm{mg} / \mathrm{kg})$ locomotion (D1: $3814.82 \pm 319.9 \mathrm{~cm} v s$ D3: $8089.64 \pm 967.4 \mathrm{~cm}$ ). Furthermore, D1 receptor mutant mice did not acquire morphine-conditioned place preference (D1: $-18.3 \pm 59.9, \mathrm{D} 3: 217.7 \pm 64.1)$ and showed decreased 
BDNF expression in the NAc (D1: $0.33 \pm 0.07$ fold, D3: $2.21 \pm 0.18$ fold) and PFC (D1: $0.74 \pm 0.15$ fold, D3: $1.68 \pm 0.22$ fold) compared with wild-type and D3 receptor mutant mice. These findings suggest that the $\mathrm{D} 1$ receptor is necessary for the induction of cue-associated morphine seeking and modulates locomotor habituation processes in response to acute morphine. The dopamine receptor $\mathrm{D} 1$ but not the $\mathrm{D} 3$ is also critical for morphine-induced BDNF expression in the NAc and PFC.

Key words: Morphine; Place preference; D1 receptor; D3 receptor; Brain-derived neurotrophic factor

\section{INTRODUCTION}

Drug addiction has been widely accepted as a chronic brain disorder and a disease of learning and memory (Wise, 2004). The mesolimbic dopamine (DA) pathway is involved in the control of motivational behavior, locomotor activity, reward, and the cognitive effects of several substances of abuse (Wise, 2004). Drugs of abuse can pathologically change neuronal circuits in the mesocorticolimbic DA system, which projects from the ventral tegmental area to the nucleus accumbens (NAc), prefrontal cortex (PFC) and other structures (Koob and Volkow, 2010). The PFC contributes to decision-making and the execution of goal-directed actions (Vertes, 2006). The NAc modulates motivation for drug seeking by integrating information from the PFC and relaying it to motor output structures, and in so doing, mediates reinforcement (Deadwyler et al., 2004).

DA modulates neurotransmission by acting at two classes of $\mathrm{G}$ protein-coupled receptors, termed D1-like (D1 and D5) and D2-like (D2, D3, and D4) receptors. These two classes of receptors are abundant in both the NAc and the PFC (Mansour et al., 1992; Diaz et al., 1995; Missale et al., 1998). In addition, there is substantial evidence that D1 and D3 receptors are particularly involved in the behavioral changes induced by drugs of abuse. D1 receptor agonists and antagonists have been found to modify drug-induced locomotor activity (Karlsson et al., 2008), responding rates (Katz et al., 1999), place preference (Pina and Cunningham, 2014) and heroinseeking behavior (Tobin et al., 2013). We previously found that mice lacking the D1 receptor did not respond to cocaine-induced locomotor-stimulant effects (Xu et al., 1994a) and conditioned place preference (CPP) (Chen and $\mathrm{Xu}, 2010)$. In addition, some D3 receptor-preferring ligands alter morphine's effects, including self-administration (David et al., 2002), morphine-induced hyperactivity (Manzanedo et al., 1999) and the establishment and expression of CPP (Vazquez et al., 2007). However, much research remains to be done to elucidate the underlying molecular mechanisms related to D1 and D3 receptors' roles in morphine-related behaviors.

Brain-derived neurotrophic factor (BDNF) is a member of the neurotrophin family and is critically involved in the development, differentiation, maintenance, and survival of neurons (Blum and Konnerth, 2005). BDNF in the NAc and PFC may play an important role in the formation of drug-conditioned stimulus associations (Horger et al., 1999; Graham et al., 2007). Furthermore, previous studies have linked D1 and D3 receptor activation to increased BDNF expression and signaling (Kuppers and Beyer, 2001; Williams and Undieh, 2009; Liang et al., 2011); however, the underlying interactions between D1 and D3 receptors and BDNF in morphine-induced locomotion and place preference have not yet been established.

In this study, we used DA receptor mutant mice to further explore the roles of the D1 
and $\mathrm{D} 3$ receptors in locomotion and morphine-induced place preference. We also investigated the effects of morphine on BDNF protein expression in the NAc and PFC of mouse brains. Our results show that the DA D1 receptor but not the D3 receptor is critical for cue-associated morphine-seeking and BDNF expression in specific areas of the brain.

\section{MATERIAL AND METHODS}

\section{Animals}

The DA D1 receptor mutant $\left(\mathrm{Dl}^{-/}\right)$mice and DA D3 receptor mutant $\left(\mathrm{D3}^{-/}\right)$mice were generated by Xu et al. (1994a; 1997). The genotypes of the mice were identified using Southern blotting with gene-specific probes (Xu et al., 1994b). Male $D 1^{--}, D 3^{-/}$and wild-type (WT) mice (C57BL/6J, 12-14 weeks, 14-30 g) were housed in groups of four per cage at constant temperature $\left(20^{\circ}-22^{\circ} \mathrm{C}\right)$ and humidity $(50-55 \%)$ under a $12 \mathrm{~h}$ light/dark cycle (lights on at 8:00 A.M.) with food and water ad libitum. The mice were allowed to habituate in the room for 7 days before the experimental manipulations. All experimental procedures were approved by the Animal Care and Use Committee of Xi'an Jiaotong University. All efforts were made to minimize the number of animals used and their suffering.

\section{Drug and antibodies}

Morphine hydrochloride was purchased from Sigma Chemical Co. (St. Louis, MO, USA) and dissolved in sterile saline. The morphine dose used in the current study was $1.0 \mathrm{mg} / \mathrm{mL}$. All injections were administered intraperitoneally $(i p)$ in a volume of $10 \mathrm{~mL} / \mathrm{kg}$ body weight. The primary antibodies against BDNF were from Abcam Technology (Cambridge, MA, USA). The primary antibodies for $\beta$-actin and the horseradish peroxidase-conjugated anti-rabbit and anti-mouse secondary antibodies were purchased from Santa Cruz Technology (Santa Cruz, CA, USA).

\section{Behavioral tests}

To assess exploratory drive and anxiety- and depression-like behaviors in the $D 1^{-1}$, $D 3^{-/}$and WT mice ( $\mathrm{N}=6$ for each genotype), two behavioral assays were carried out.

\section{Open-field test}

A black square arena $(45 \mathrm{~cm} \times 45 \mathrm{~cm} \times 30 \mathrm{~cm})$ under homogenous illumination (150 Lux) was used. The arena was divided into a central zone ( $40 \%$ of the total area) and a peripheral zone (60\% of the total area) (Prut and Belzung, 2003) by the video-tracking software (SMART, Panlab SL, Barcelona, Spain). Thirty minutes after a single dose of morphine, mice were placed in the peripheral zone and allowed to explore the apparatus freely for $15 \mathrm{~min}$. Total distance, average velocity (locomotion), distance in the center zone and center zone entries were analyzed.

\section{Forced swim test}

Thirty minutes after receiving a morphine injection, mice were forced to swim in a Plexiglas cylinder (height $20 \mathrm{~cm}$, diameter $19 \mathrm{~cm}$ ) with water at a depth of $10 \mathrm{~cm}\left(25^{\circ} \mathrm{C}\right)$ for 10 
$\min$. Mouse performance in the cylinder was videotaped and scored by an observer blind to treatment condition. Immobility (depressive-like behavior) was defined as the absence of all movement except those movements necessary to keep the head above water (Schroeder et al., 2007).

\section{Conditioned place preference}

In a separate series of experiments, mice of each genotype were randomly assigned to three groups: the homecage group, the saline-treated group and the morphine-treated group ( $\mathrm{N}$ =5-6/group). The CPP apparatus consisted of two compartments $(16.8 \mathrm{~cm} \times 12.7 \mathrm{~cm} \times 12.7$ $\mathrm{cm}$ ) that had different visual and tactile cues. One compartment was black with a stainless steel grid rod floor. The other compartment was white with a stainless steel mesh floor. The two compartments were separated by an opaque partition.

We used a biased CPP procedure similar to that described before (Chen and $\mathrm{Xu}, 2010)$ with modifications. During the preconditioning phase (day 1, pre-test), mice were placed in the CPP apparatus and were allowed to freely explore the two compartments for $15 \mathrm{~min}$. The time spent in each compartment was recorded. Mice that spent more than $600 \mathrm{~s}$ of the $15 \mathrm{~min}$ period in either compartment or crossed between the compartments fewer than 20 times were excluded from analysis (4 of 54 mice). The next 12 days (days 2-13) comprised the conditioning and testing phases of the test. The morphine-treated group received an ip morphine injection $(10 \mathrm{mg} / \mathrm{kg}$ body weight) and was confined to the white compartment for $40 \mathrm{~min}$ on day 2. On day 3, this group of mice received a volume-matched saline injection and was confined to the black compartment for $40 \mathrm{~min}$. As a control, the saline group received ip saline injections on days 2 and 3 before being confined to each compartment. On day 4 (test 1), the mice were allowed to freely explore the three compartments for $15 \mathrm{~min}$ without injections, and the time spent in each compartment was recorded. Each mouse experienced four conditioning sessions (days 5-6, 8-9, 11-12) and testing sessions (days 7, 10, 13). The mice were sacrificed by decapitation immediately after test 4 (day 13), and brain tissues from the NAc and PFC were dissected out and stored at $-80^{\circ} \mathrm{C}$ until used for assay.

\section{Protein extraction and immunoblotting}

The brain samples were homogenized in $50 \mathrm{mM}$ radio immunoprecipitation assay buffer $(20 \mu \mathrm{L} / \mathrm{mg})$ containing a protease inhibitor cocktail and phosphatase inhibitor cocktail. The homogenates were incubated on ice for $30 \mathrm{~min}$ and centrifuged at 12,000 $\mathrm{g}$ for $15 \mathrm{~min}$ at $4{ }^{\circ} \mathrm{C}$. The protein content was determined using the bicinchoninic acid method (Joincare Co., Zhuhai, China). The protein samples were mixed with equal volumes of electrophoresis loading buffer, denatured and stored at $-80^{\circ} \mathrm{C}$ until ready to be used. Then, the samples, which contained $15 \mu \mathrm{g}$ of total protein, were denatured at $95^{\circ} \mathrm{C}$ for $5 \mathrm{~min}$, separated by $12 \%$ sodium dodecyl sulfate-polyacrylamide gelelectrophoresis and transferred to poly-vinylidene fluoride membranes. The membranes were blocked with 5\% non-fat milk in Tris-buffered saline (500 $\mathrm{mM} \mathrm{NaCl}, 20 \mathrm{mM}$ Tris-HCl, $\mathrm{pH} 7.5$ ) containing $0.05 \%$ Tween-20 for $1 \mathrm{~h}$. The membranes were incubated with primary antibodies against BDNF or $\beta$-actin (Abcam, MA, USA), gently agitated overnight at $4^{\circ} \mathrm{C}$, incubated with anti-rabbit or anti-mouse secondary antibody conjugated to horseradish peroxidase and developed using enhanced chemiluminescence (Millipore, MA, USA). The bands were normalized to $\beta$-actin. All Western blot analyses were performed at least three times, and parallel results were obtained. The autoradiogram bands of the BDNF 
proteins in the PFC and NAc were analyzed using the Image-Pro Plus program. The integrated optical densities of protein bands were compared to determine their levels of expression.

\section{Data analysis}

All data are reported as means \pm SE. The data were analyzed using a two-way ANOVA followed by Bonferroni's post hoc test. The CPP scores were expressed as time spent on the saline-paired side subtracted from time spent on the morphine-paired side. The results from the Western blot were analyzed using densitometry. The ratio of BDNF to $\beta$-actin was calculated for each sample. The homecage controls were set at 1 . Values of $\mathrm{P}<0.05$ were considered to be statistically significant.

\section{RESULTS}

\section{Dopamine D1 receptor but not D3 receptor mutant mice showed decreased sensitivity to morphine-induced locomotor effects}

A two-way ANOVA of total distance traveled in the open-field test (OFT) revealed a significant genotype effect [Figure $1 \mathrm{~A}, \mathrm{~F}_{\text {genotype }(2,30)}=35.61, \mathrm{P}<0.001$ ]. In the open-field arena, the WT and $D 3^{-/}$mice showed significantly enhanced locomotor activity after acute morphine administration (post hoc tests, both $\mathrm{P}<0.0001$ ). No significant change in total distance was observed in the $\mathrm{Dl}^{-/}$mice. Furthermore, distance traveled in the central zone was also significantly affected by genotype [Figure $\left.1 \mathrm{~B} \mathrm{~F}_{\text {genotype }(2,30)}=8.930, \mathrm{P}<0.01\right]$ and morphine treatment $\left[\mathrm{F}_{\text {treatment }(1,30)}=6.099, \mathrm{P}<0.05\right]$. Subsequent post hoc tests indicated that morphine significantly decreased distance traveled in the central zone in both the WT and $D 3^{-\leftarrow}$ mice $(\mathrm{P}<0.05$ and $\mathrm{P}<$ 0.0001 , respectively). However, no significant change in central distance was observed in the $D 1^{-/}$mice after morphine injection. There was no difference in average velocity (Figure 1C), center zone entries (Figure 1D) or immobility time (Figure 2) between the three genotypes of mice following morphine treatment.
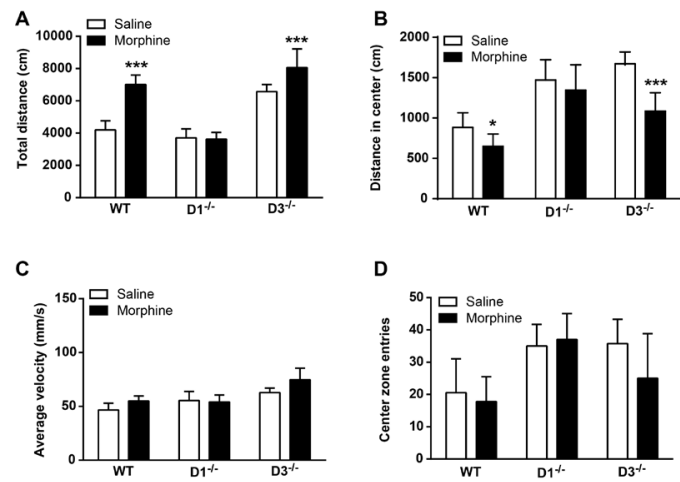

Figure 1. Morphine-induced locomotor behaviors in dopamine receptor D1 $\left(D 1^{-/}\right)$or $\mathrm{D} 3\left(\mathrm{D}^{-/}\right)$mutant mice. The $D 1^{-/}$but not the $\mathrm{D}^{-/}$mice showed decreased sensitivity to morphine-induced locomotor effects. The $D 1^{--}$and $D 3^{-/}$receptor mutant mice $(\mathrm{N}=6 /$ group$)$ were given a single dose of morphine $(10.0 \mathrm{mg} / \mathrm{kg})$ intraperitoneally and subjected to an open-field test. (A) Total distance, (B) center zone distance, $(\mathbf{C})$ average velocity and (D) center zone entries were analyzed. Values are reported as means $\pm \mathrm{SE} . * \mathrm{P}<0.05 ; * * * \mathrm{P}<0.0001$ vs saline controls of the same genotype. WT = wild-type mice. 


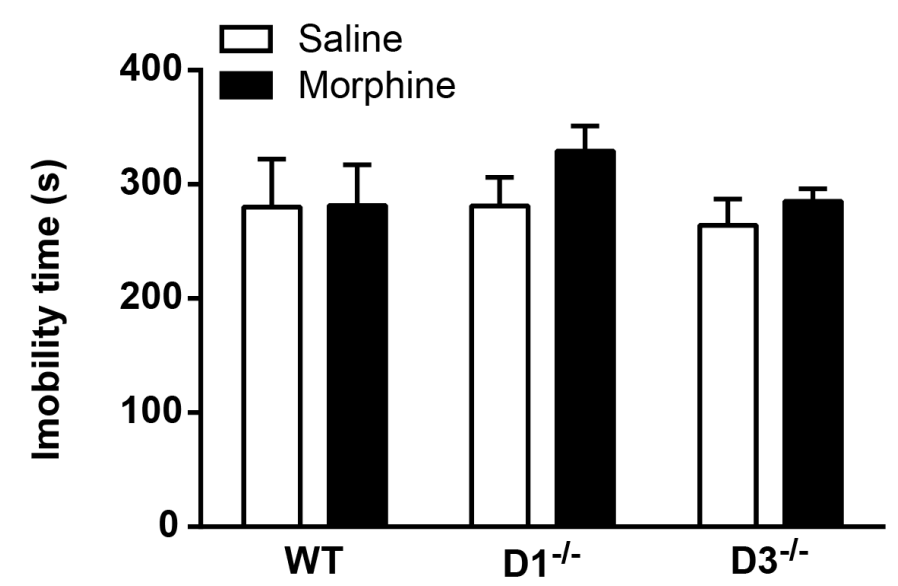

Figure 2. Morphine-induced effects on immobility in dopamine $\mathrm{D} 1\left(\mathrm{D1^{-/ }}\right)$ and $\mathrm{D} 3\left(\mathrm{D1^{-/ }}\right)$ receptor mutant mice. $D 1^{-}$ and $D 3^{-/}$mice $(\mathrm{N}=6 /$ group$)$ were given a single dose of morphine $(10.0 \mathrm{mg} / \mathrm{kg})$ intraperitoneally and subjected to a forced swim test during which time spent immobile was measured. WT = wild-type mice.

\section{DA D1 receptor mutant mice do not acquire morphine-induced CPP}

Next, we investigated the role of the D1 and D3 receptors in the rewarding effects of morphine at the dose of $1.0 \mathrm{mg} / \mathrm{kg}$ (Figure 3). No significant difference was observed in basal CPP score (pretest) between the three genotypes of mice. In test 2, there was a significant effect of treatment $\left[\mathrm{F}_{\text {treatment }(1,30)}=10.78, \mathrm{P}<0.01\right]$ but not genotype $\left[\mathrm{F}_{\text {genotype }(2.30)}=2.246, \mathrm{P}=0.123\right]$ after conditioning. Furthermore, the morphine-paired $D 3^{--}$mice showed a significant CPP $(\mathrm{P}<0.05)$ and the WT mice showed a nearly significant CPP $(\mathrm{P}=0.0543)$ compared with their saline-paired counterparts. Following four conditioning sessions (test 4), the analysis revealed a significant effect of both treatment and genotype $\left[\mathrm{F}_{\text {treatment }(1,30)}=9.607, \mathrm{P}<0.01\right.$; $\left.\mathrm{F}_{\text {genotype }(2,30)}=6.77, \mathrm{P}<0.05\right]$ as well as their interaction $\left[\mathrm{F}_{\text {treatment } x \text { genotype }(2,30)}=3.504, \mathrm{P}<0.05\right]$ on CPP scores. The post hoc comparisons indicated that both the D $3^{--}$and WT mice developed CPP after conditioning $\left(D 3^{-}: \mathrm{P}<0.0001\right.$; WT: $\left.\mathrm{P}<0.05\right)$ compared with their saline-paired controls, whereas the $D 1^{-/}$mice did not $(\mathrm{P}=0.126)$. The $D 1^{-/}, D 3^{--}$and WT mice did not show $\mathrm{CPP}$ acquisition with saline injections throughout the experiment, indicating that the injection itself does not affect place preference.

\section{The DA D1 receptor but not the D3 receptor is critical for morphine-induced BDNF expression in the NAc and PFC}

Because $D 1^{-/}$mice do not readily acquire morphine-induced CPP, we next investigated whether there is a corresponding change in BDNF protein expression in the NAc and $\mathrm{PFC}$ in the D1 and D3 receptor mutant mice. An ANOVA of BDNF expression in the NAc showed a significant genotype effect $\left[\mathrm{F}_{\text {genotype }(2,45)}=27.33, \mathrm{P}<0.0001\right]$, treatment effect $\left[\mathrm{F}_{\text {treat- }}\right.$ ment $(2,45)=22.65, \mathrm{P}<0.0001]$ and genotype $\mathrm{x}$ treatment interaction $\left[\mathrm{F}_{\text {treatment } x \text { genotype }(4,45)}=21.48\right.$, $\mathrm{P}<0.0001]$ (Figure 4A). The post hoc comparisons showed a significant increase in BDNF in the NAc in both the morphine-paired WT and $D 3^{-/}$mice (compared with homecage, both $\mathrm{P}<0.0001)$ after CPP acquisition. In contrast, an obvious decrease in BDNF was observed 
in the NAc of the $D 1^{-/}$mice $(\mathrm{P}<0.05)$. In the $\mathrm{PFC}$, there was a significant effect of genotype $\left[\mathrm{F}_{\text {genotype (2.45) }}=5.232, \mathrm{P}<0.01\right]$, treatment $\left[\mathrm{F}_{\text {treatment }(2.45)}=7.522, \mathrm{P}<0.01\right]$ and a strong genotype $\mathrm{x}$ treatment interaction $\left[\mathrm{F}_{\text {treatment } \mathrm{x} \text { genotype }(4,45)}=7.801, \mathrm{P}<0.0001\right]$ on BDNF levels (Figure 4B). Increased BDNF levels were found in both the morphine-paired WT and $D 3^{--}$mice (post hoc tests, both $\mathrm{P}<0.05$, compared with homecage) with no obvious change in the $D 1^{-/}$mice. BDNF expression was similar in both brain regions between all genotypes following saline treatment.

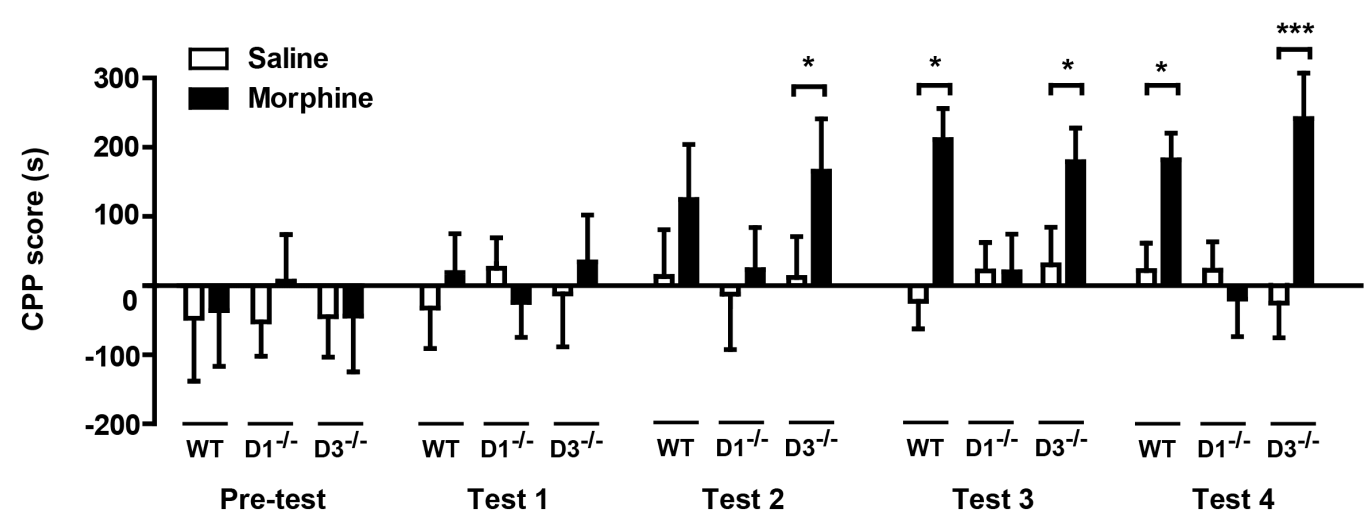

Figure 3. Dopamine D1 $\left(D 1^{-/}\right)$receptor mutant mice do not acquire morphine-induced CPP. The $D 1^{-/}, D 3^{-/}$and wild-type (WT) mice received repeated injections alternating between morphine $(10.0 \mathrm{mg} / \mathrm{kg})$ and saline $(\mathrm{N}=5-6 /$ group) and were confined to CPP chambers. The mice were then tested for their place preference without injections at the indicated time points. The CPP scores represent time spent on the drug-paired side minus time on the salinepaired side. ${ }^{*} \mathrm{P}<0.05 ; * * * \mathrm{P}<0.0001$ vs saline controls of the same genotype. WT $=$ wild-type mice.

A
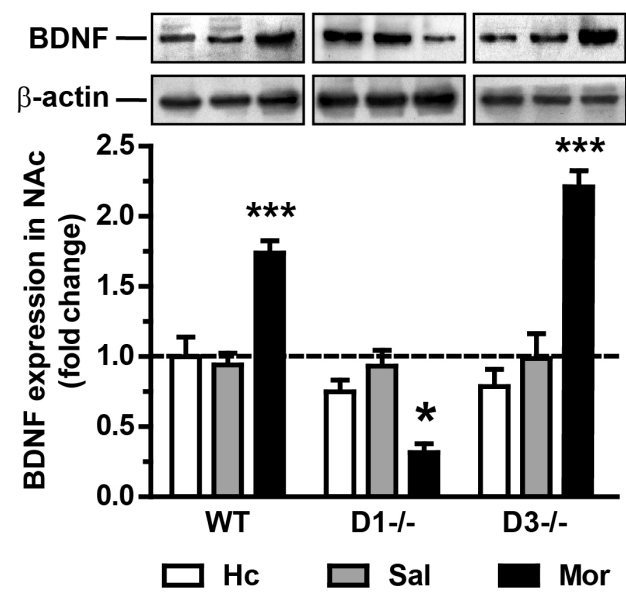

B
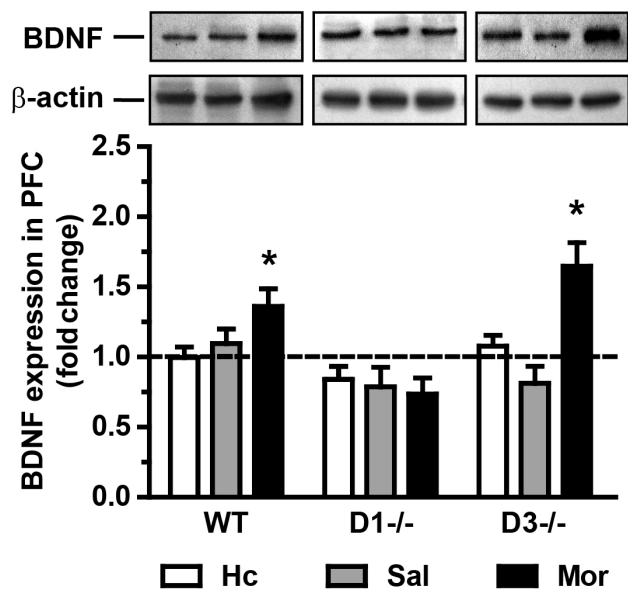

Figure 4. Morphine-induced BDNF expression. BDNF expression in the (A) NAc and (B) PFC of dopamine D1 $\left(\mathrm{Dl}^{-/}\right)$and $\mathrm{D} 3\left(\mathrm{Dl}^{-/}\right)$receptor mutant mice were determined by Western blot. The mice were sacrificed at the end of the fourth CPP test. Data are reported as means \pm SE relative to the WT saline controls that were set as 1 . $\beta$-actin levels were used as a loading control. $* \mathrm{P}<0.05 ; * * * \mathrm{P}<0.0001$ compared with the saline control group of the same genotype. $\mathrm{Hc}=$ homecage control; $\mathrm{Sal}=$ saline-injected; $\mathrm{Mor}=$ morphine-injected; $\mathrm{WT}=$ wild-type mice. 


\section{DISCUSSION}

The aim of the present study was to explore the roles of D1 and D3 receptors in morphine-stimulated locomotion and reward-related behaviors, and further, to investigate the effects of morphine on BDNF protein expression in specific regions of the mouse brain such as the NAc and PFC. We found that mice lacking the D1 receptor but not the D3 receptor demonstrated reduced locomotor activity in response to acute morphine. The OFT is commonly used to assess the sedative, toxic, or stimulant effects of compounds. It is based on the natural tendency of an animal to explore and use the avoidance reaction to protect itself, which makes normal animals spend more time in the corners and the periphery than in the center (the most anxiogenic area) (Choleris et al., 2001). An increase in activity in the central zone during the test likely reflects various aspects of emotionality, including decreased anxiety and increased exploratory drive (Wang et al., 2012). Rezayof et al. (2013) demonstrated in the elevated plus-maze that ip administration of morphine $(5,7.5$, and $10 \mathrm{mg} / \mathrm{kg}$ ) increased the percentage of open arm time and open arm entries, suggesting an anxiolytic-like response to morphine. In the present study, four behavioral parameters were analyzed: total distance and average velocity reflect locomotor activity, while reduced center distance and center entries reflect anxiety-like behavior. The results of the OFT showed that morphine exerted locomotor stimulant effects on the WT and $\mathrm{D}^{-/}$mice. Locomotor effects were not observed in the $\mathrm{DI}^{-/}$mice, indicating a critical role for the DA D1 receptor in modulating sensitivity to morphine-induced locomotion.

It is known that environmental stimuli (people, places, and things) associated with drug use can trigger intense cravings in addicted patients (Dackis and O'Brien, 2005). Among the various experimental protocols that have been used to measure the rewarding effects of drugs in laboratory animals, CPP has been one of the most popular. CPP appears to reflect a preference for a context due to the contiguous association between the context and a drug stimulus (Bardo and Bevins, 2000). One major finding of our study was the reduction in morphine reward sensitivity in mice lacking the D1 but not the D3 receptor. Previous research showed that the D1 and D3 receptors are differentially involved in learning associations between cues and the rewarding properties of drugs of abuse. The $D 1^{-/}$mice failed to acquire CPP, whereas the $D 3^{-/}$mutant mice show a delayed CPP extinction compared with WT mice (Chen and Xu, 2010). The intrahippocampal administration of the D1 receptor antagonist SCH 23390 can block morphineinduced CPP and significantly decrease intra-VTA morphine-induced CPP (Esmaeili et al., 2012). Furthermore, the $D 3^{-/}$mice showed a similar morphine CPP induction to that of the WT mice, which is also in agreement with previous findings (Karasinska et al., 2005).

We previously reported that the BDNF protein levels were significantly decreased in the PFC of the $\mathrm{DI}^{-\leftarrow}$ mice, whereas no changes were found in the $\mathrm{D3}^{-/}$mice (Xing et al., 2012). Furthermore, Williams and Undieh (2009) showed that the D1 receptor agonist SKF38393 can produce a significant increase in BDNF protein levels in striatal and hippocampal tissue slices. These findings suggest that the induction of BDNF expression may constitute a downstream response to D1-like dopamine receptor activation. In the present study, we demonstrated that the DA D1 receptor but not the D3 receptor is necessary for morphine-induced BDNF expression in the NAc and PFC. After morphine conditioning, the $\mathrm{D1}^{-/}$mice showed significantly decreased BDNF expression in the NAc and PFC compared with WT and D3- mice. Similarly, Pina and Cunningham (2012) demonstrated that the blockade of the DA D1 but not D2 receptor impairs the development of ethanol-induced CPP. In the case of cocaine, the levels of 
striatal BDNF and its receptor TrkB were significantly higher in mice following prenatal cocaine or D1 agonist treatment (Tropea et al., 2011). Furthermore, D3־ mice showed a delayed cocaine-CPP extinction and sustained extracellular regulated protein kinases activation, which is thought to be an upstream signal of BDNF expression, in the NAc and PFC compared with WT mice (Chen and Xu, 2010). These studies all support the notion that the DA D1 receptor but not the D3 receptor modulates BDNF expression in different brain regions during the acquisition of cue-associated morphine seeking.

In conclusion, these findings suggest that the D1 receptor is necessary for the induction of cue-associated morphine seeking and modulates locomotor habituation processes in response to acute morphine. Moreover, our results suggest that the DA D1 receptor but not the D3 receptor is critical for morphine-induced BDNF expression in the NAc and PFC.

\section{ACKNOWLEDGMENTS}

Research supported by the National Science Foundation of China (\#NSFC 31271340).

\section{REFERENCES}

Bardo MT and Bevins RA (2000). Conditioned place preference: what does it add to our preclinical understanding of drug reward? Psychopharmacology 153: 31-43.

Blum R and Konnerth A (2005). Neurotrophin-mediated rapid signaling in the central nervous system: mechanisms and functions. Physiology 20: 70-78.

Chen L and Xu M (2010). Dopamine D1 and D3 receptors are differentially involved in cue-elicited cocaine seeking. J. Neurochem. 114: 530-541.

Choleris E, Thomas AW, Kavaliers M and Prato FS (2001). A detailed ethological analysis of the mouse open field test: effects of diazepam, chlordiazepoxide and an extremely low frequency pulsed magnetic field. Neurosci. Biobehav. Rev. 25: 235-260.

Dackis C and O'Brien C (2005). Neurobiology of addiction: treatment and public policy ramifications. Nat. Neurosci. 8: 1431-1436.

David V, Durkin TP and Cazala P (2002). Differential effects of the dopamine D2/D3 receptor antagonist sulpiride on self-administration of morphine into the ventral tegmental area or the nucleus accumbens. Psychopharmacology 160: 307-317.

Deadwyler SA, Hayashizaki S, Cheer J and Hampson RE (2004). Reward, memory and substance abuse: functional neuronal circuits in the nucleus accumbens. Neurosci. Biobehav. Rev. 27: 703-711.

Diaz J, Levesque D, Lammers CH, Griffon N, et al. (1995). Phenotypical characterization of neurons expressing the dopamine D3 receptor in the rat brain. Neuroscience 65: 731-745.

Esmaeili MH, Kermani M, Parvishan A and Haghparast A (2012). Role of D1/D2 dopamine receptors in the CA1 region of the rat hippocampus in the rewarding effects of morphine administered into the ventral tegmental area. Behav. Brain. Res. 231: 111-115.

Graham DL, Edwards S, Bachtell RK, DiLeone RJ, et al. (2007). Dynamic BDNF activity in nucleus accumbens with cocaine use increases self-administration and relapse. Nat. Neurosci. 10: 1029-1037.

Horger BA, Iyasere CA, Berhow MT, Messer et al. (1999). Enhancement of locomotor activity and conditioned reward to cocaine by brain-derived neurotrophic factor. J. Neurosci. 19: 4110-4122.

Karasinska JM, George SR, Cheng R and O'Dowd BF (2005). Deletion of dopamine D1 and D3 receptors differentially affects spontaneous behaviour and cocaine-induced locomotor activity, reward and CREB phosphorylation. Eur. J. Neurosci. 22: 1741-1750.

Karlsson RM, Hefner KR, Sibley DR and Holmes A (2008). Comparison of dopamine D1 and D5 receptor knockout mice for cocaine locomotor sensitization. Psychopharmacology 200: 117-127.

Katz JL, Kopajtic TA, Myers KA, Mitkus RJ, et al. (1999). Behavioral effects of cocaine: interactions with D1 dopaminergic antagonists and agonists in mice and squirrel monkeys. J. Pharmacol. Exp. Ther. 291: 265-279.

Koob GF and Volkow ND (2010). Neurocircuitry of addiction. Neuropsychopharmacology 35: 217-238.

Kuppers E and Beyer C (2001). Dopamine regulates brain-derived neurotrophic factor (BDNF) expression in cultured 
embryonic mouse striatal cells. Neuroreport. 12: 1175-1179.

Liang J, Zheng X, Chen J, Li Y, et al. (2011). Roles of BDNF, dopamine D(3) receptors, and their interactions in the expression of morphine-induced context-specific locomotor sensitization. Eur. Neuropsychopharmacol. 21: 825-834.

Mansour A, Meador-Woodruff JH, Zhou Q, Civelli O, et al. (1992). A comparison of D1 receptor binding and mRNA in rat brain using receptor autoradiographic and in situ hybridization techniques. Neuroscience 46: 959-971.

Manzanedo C, Aguilar MA and Minarro J (1999). The effects of dopamine D2 and D3 antagonists on spontaneous motor activity and morphine-induced hyperactivity in male mice. Psychopharmacology 143: 82-88.

Missale C, Nash SR, Robinson SW, Jaber M, et al. (1998). Dopamine receptors: from structure to function. Physiol. Rev. 78: $189-225$.

Pina MM, and Cunningham CL (2012). Dopamine D1 but not D2 receptor blockade impairs the development of ethanolconditioned place preference. Alcohol. Clin. Exp. Res. 36: 193a.

Pina MM and Cunningham CL (2014). Effects of dopamine receptor antagonists on the acquisition of ethanol-induced conditioned place preference in mice. Psychopharmacology 231: 459-468.

Prut L and Belzung C (2003). The open field as a paradigm to measure the effects of drugs on anxiety-like behaviors: a review. Eur. J. Pharmacol. 463: 3-33.

Rezayof A, Assadpour S and Alijanpour S (2013). Morphine-induced anxiolytic-like effect in morphine-sensitized mice: involvement of ventral hippocampal nicotinic acetylcholine receptors. Pharmacol. Biochem. Behav. 103: 460-466.

Schroeder FA, Lin CL, Crusio WE and Akbarian S (2007). Antidepressant-like effects of the histone deacetylase inhibitor, sodium butyrate, in the mouse. Biol. Psychiatry 62: 55-64.

Tobin S, Sedki F, Abbas Z and Shalev U (2013). Antagonism of the dopamine D1-like receptor in mesocorticolimbic nuclei attenuates acute food deprivation-induced reinstatement of heroin seeking in rats. Eur. J. Neurosci. 37: 972981.

Tropea TF, Kabir ZD, Kaur G, Rajadhyaksha AM, et al. (2011). Enhanced dopamine D1 and BDNF signaling in the adult dorsal striatum but not nucleus accumbens of prenatal cocaine treated mice. Front. Psychiatry 2: 67.

Vazquez V, Weiss S, Giros B, Martres MP, et al. (2007). Maternal deprivation and handling modify the effect of the dopamine D3 receptor agonist BP 897 on morphine-conditioned place preference in rats. Psychopharmacology 193: 475-486.

Vertes RP (2006). Interactions among the medial prefrontal cortex, hippocampus and midline thalamus in emotional and cognitive processing in the rat. Neuroscience 142: 1-20.

Wang Y, Cui H, Wang W, Zhao B, et al. (2012). The region-specific activation of $\mathrm{Ca}^{2+} /$ calmodulin dependent protein kinase II and extracellular signal-regulated kinases in hippocampus following chronic alcohol exposure. Brain Res. Bull. 89: 191-196.

Williams SN and Undieh AS (2009). Dopamine D1-like receptor activation induces brain-derived neurotrophic factor protein expression. Neuroreport. 20: 606-610.

Wise RA (2004). Dopamine, learning and motivation. Nat. Rev. Neurosci. 5: 483-494.

Xing B, Guo J, Meng X, Wei SG, et al. (2012). The dopamine D1 but not D3 receptor plays a fundamental role in spatial working memory and BDNF expression in prefrontal cortex of mice. Behav. Brain. Res. 235: 36-41.

Xu M, Hu XT, Cooper DC, Moratalla R, et al. (1994a). Elimination of cocaine-induced hyperactivity and dopaminemediated neurophysiological effects in dopamine D1 receptor mutant mice. Cell 79: 945-955.

Xu M, Moratalla R, Gold LH, Hiroi N, et al. (1994b). Dopamine D1 receptor mutant mice are deficient in striatal expression of dynorphin and in dopamine-mediated behavioral responses. Cell 79: 729-742.

Xu M, Koeltzow TE, Santiago GT, Moratalla R, et al. (1997). Dopamine D3 receptor mutant mice exhibit increased behavioral sensitivity to concurrent stimulation of D1 and D2 receptors. Neuron. 19: 837-848. 